\title{
Study the Role Serum Omentin-1 in Occurrence and Development of Diabetic Retinopathy
}

\author{
Hussein Inam Mustafa ${ }^{1}$, Sami A. Zbaar ${ }^{2}$, Marwan Salah Salman ${ }^{3}$ \\ ${ }^{1}$ M.Sc. Student, Medical Biochemistry, Kirkuk Health Directorate, ${ }^{2}$ Ph.D. Medical Biochemistry, College of \\ Medicine, Tikrit University, ${ }^{3}$ Ph.D. Ophthalmology, College of Medicine, Tikrit University
}

\begin{abstract}
Diabetic retinopathy (DR) is a retinal disease which is one of the most severe micro vascular complications occurring due to diabetes mellitus and is a major cause of blindness. The aim of this work was to study the serum level of omentin- 1 and its relation to diabetic retinopathy in type 2 diabetes mellitus. The study included 60 diabetic patients (30 patients T2DM complicated with DR and 30 patients T2DM not complicated with DR). The study also included 30 healthy control individuals defended as subjects who apparently haven't any chronic diseases. Thorough history taking and physical examination with calculation of body mass index (BMI), investigations were done including HbAlc, C-reactive protein (CRP) and serum omentin-1. Fundus examination was carried out by an expert ophthalmologist. The study showed that serum omintin-1 was reduced significantly $(\mathrm{P}<0.001)$ in DM patients $(15.29 \pm 3.69 \mathrm{ng} / \mathrm{ml})$ as compared with the control group $(24.95 \pm 4.22 \mathrm{ng} / \mathrm{ml})$, Table 1 . The study also showed that serum omintin-1 was reduced significantly $(\mathrm{P}<0.001)$ in DR patients $(12.39 \pm 2.21 \mathrm{ng} / \mathrm{ml})$, comparing with DM patients without retinopathy $(17.52 \pm 2.28 \mathrm{ng} / \mathrm{ml})$. The study revealed that the highest mean of $\mathrm{HbAlc}$ was found in DM patients $(8.39 \pm 1.62 \%)$ as compared by the control group $(4.91 \pm 0.43 \%)(\mathrm{P}<0.001)$, Table 3 . The study also found that $\mathrm{HbA1c}$ was elevated significantly $(\mathrm{P}<0.001)$ in DR patients $(9.38 \pm 1.65 \%)$ comparing with DM patients without retinopathy $(7.66 \pm 0.79 \%)(\mathrm{P}<0.001)$. The study showed that, the highest mean of serum CRP was recorded in DM patients $(7.89 \pm 1.76 \mathrm{mg} / \mathrm{dl})$, as compared with the control group $(4.51 \pm 0.72 \mathrm{mg} /$ dl) $(\mathrm{P}<0.001)$, Table 5. The study also found that $\mathrm{CRP}$ was elevated significantly $(\mathrm{P}<0.001)$ in $\mathrm{DR}$ patients $(9.37 \pm 1.11 \mathrm{mg} / \mathrm{dl})$ as compared with diabetic without retinopathy patients $(6.41 \pm 0.73 \mathrm{mg} / \mathrm{dl})$, The study showed that $60 \%$ DR patients suffered from T2D for more than 9 years and $40 \%$ suffered DM for 7-9 years while all diabetic patients without retinopathy were suffered from T2D for $\leq 9$ years with a significant relation between $\mathrm{Dr}$ and the duration of diabetes $(\mathrm{P}<0.001)$. The study showed negative correlation of serum omentin-1 concentrations with duration of diabetes, BMI, HbA1c and CRP. From this study we can conclude that serum omentin-1 levels are correlated with the presence and severity of DR.
\end{abstract}

Keywords: Omentin-1; Type 2 diabetes mellitus; Diabetic retinopathy; HbAlc.

\section{Introduction}

Diabetic retinopathy (DR) is a chronic ocular complication of diabetes that is seen to some degree in approximately one-third of diabetic patients ${ }^{(1)}$. Approximately one-third of patients with diabetic retinopathy have vision-threatening retinopathy (i.e., diabetic macular edema, severe non-proliferative diabetic retinopathy, or proliferative diabetic retinopathy $)^{(2)}$. The rate of progression varies depending on the duration of the disease, glycemic control, hypertension, and genetics. Proliferative diabetic retinopathy (PDR) is diagnosed in the presence of retinal or disc neovascularization, a consequence of retinal ischemia ${ }^{(3)}$. Overall, the rate of progression to PDR and severe vision loss has decreased in the last two decades, most likely due to improvement in diabetic care ${ }^{(4)}$. The risk of developing advanced PDR correlates directly with markers of glycemic exposure (such as HbAlc, duration of diabetes), hypertension, cardiovascular disease events, and albuminuria and inversely with age at diabetes diagnosis and, surprisingly, smoking ${ }^{(5)}$. Omentin-1 is a novel peptide adipocytokine which was first acknowledged from cDNA library 
consisting of human omental white adipose tissue $(\text { WAT })^{(6)}$. It is an adipocytokine which is released from omental and epicardial adipose tissue; and also from blood vessels, intestinal and respiratory airway goblet cells, mesothelial cells and ovary. The major effects of this secretory adipokine are the positive influences on insulin sensitivity and reduction of inflammation ${ }^{(7)}$. In human adipocytes, it has been found to play a role in promoting insulin-induced glucose uptake via protein kinase $\mathrm{B}(\mathrm{PKB})$ phosphorylation ${ }^{(8)}$. It mainly acts by suppressing ERK/NF-KB pathway or $\mathrm{p} 38 / \mathrm{JNK}$ pathway mediated inflammation. In patients with obesity, insulin resistance and DM, the circulating concentration of omentin-1 is found to be reduced. As it is a protective molecule against insulin resistance and inflammation, it is worthwhile to study the role of omentin-1 in the pathogenesis of diabetic retinopathy ${ }^{(9,10)}$. In this study, we aimed to assess and compare the level of omentin-1 in the serum of patients with type 2 diabetes mellitus with and without diabetic retinopathy.

\section{Materials and Method}

This case-control study was carried out in Kirkuk city from the period started from $1^{\text {st }}$ of December 2019 to the end of February 2020. The study included 60 diabetic patients (30 patients T2DM complicated with DR and 30 patients T2DM not complicated with DR), their age between 45-64 years, these patients who attended Kirkuk General Hospital. Diabetic retinopathy was defined according to Fundus examination which carried out to all participants by an expert ophthalmologist. The study also included 30 healthy control individuals defended as subjects who apparently haven't any chronic diseases. All participants were subjected to thorough history with special emphasis on age, sex and duration of DM. Complete physical examination performed to all subject with estimation of weight and height to calculate body mass index(BMI). Investigations included $\mathrm{HbAlc}$ by immunofluorescence technique (i- chroma II), C-reactive protein by immunofluorescence technique (i-chroma II), urine albumin creatinine ratio by testing micro-albumin and creatinine in urine (manual biochemical kits), and serum omentin-1 level was measured using an enzymelinked immune sorbent assay.

Exclusion Criteria: Type 1 diabetes, Diabetic nephropathy (UACR more than $30 \mathrm{mg} / \mathrm{g}$ ), Diabetic neuropathy, Chronic inflammatory diseases (e.g. rheumatoid arthritis), collagen disease, and chronic infections, History of malignancies, Heart diseases.

Statistical Analysis: Computerized statistically analysis was performed using Minitab version 23 statistic program. Comparison was carried out using Chi-square $\left(\mathrm{X}^{2}\right)$, T-Test probability and ANOVA (analysis of variance). The $P$ value $>0.05$ was considered statistically significant, while for those which its $\mathrm{P}$ value was greater than 0.05 considered non-significant statistically.

\section{Result}

The study showed that serum omintin-1 was reduced significantly $(\mathrm{P}<0.001)$ in DM patients $(15.29 \pm 3.69 \mathrm{ng} /$ $\mathrm{ml})$ as compared with the control group $(24.95 \pm 4.22 \mathrm{ng} /$ $\mathrm{ml}$ ), Table 1 . The study also showed that serum omintin-1 was reduced significantly $(\mathrm{P}<0.001)$ in $\mathrm{DR}$ patients $(12.39 \pm 2.21 \mathrm{ng} / \mathrm{ml})$, comparing with $\mathrm{DM}$ patients without retinopathy $(17.52 \pm 2.28 \mathrm{ng} / \mathrm{ml})$, Table 2 .

Table 1: Levels of serum omentin-1 in the studied groups

\begin{tabular}{|l|c|c|c|c|}
\hline Omentin-1 (ng/ml) & Type 2 diabetic patients (n:60) & Control group (n:30) & T. Test & P. value \\
\cline { 1 - 3 } Mean & 15.29 & 24.95 & \multirow{2}{*}{10.67} & $<0.001$ \\
\hline SD & 3.69 & 4.22 & & \multirow{2}{*}{} \\
\hline
\end{tabular}

Table 2: Levels of serum omentin-1 in the DM patients (with and without retinopathy)

\begin{tabular}{|l|c|c|c|c|}
\hline \multirow{2}{*}{ Omentin-1 (ng/ml) } & \multicolumn{2}{|c|}{ Type 2 diabetic patients } & \multirow{2}{*}{ T. Test } & \multirow{2}{*}{ P. value } \\
\cline { 2 - 3 } & Retinopathy (n:30) & Without retinopathy (n:30) & \multirow{2}{*}{11.57} & $<0.001$ \\
\hline Mean \pm SD & $12.39 \pm 2.21$ & $17.52 \pm 2.28$ & & \\
\hline Minimum & 8.6 & 22.01 & \\
\hline Maximum & 16.6 & & & \\
\hline
\end{tabular}


The study revealed that the highest mean of $\mathrm{HbA} 1 \mathrm{c}$ was found in DM patients $(8.39 \pm 1.62 \%)$ as compared by the control group $(4.91 \pm 0.43 \%)(\mathrm{P}<0.001)$, Table 3 . The study also found that $\mathrm{HbA} 1 \mathrm{c}$ was elevated significantly
$(\mathrm{P}<0.001)$ in DR patients $(9.38 \pm 1.65 \%)$ comparing with DM patients without retinopathy $(7.66 \pm 0.79 \%)$ $(\mathrm{P}<0.001)$, Table 4 .

Table 3: Relation of HbA1c with diabetic retinopathy

\begin{tabular}{|l|c|c|c|c|}
\hline HbA1c (\%) & Type 2 diabetic patients (n:60) & Control group (n:30) & T. Test & P. value \\
\cline { 1 - 3 } \pm MD & 8.39 & 4.91 & \multirow{2}{*}{15.55} & $<0.001$ \\
\hline Minimum & 1.62 & 0.43 & & \\
\hline
\end{tabular}

Table 4: Mean of HbA1c in in DM patients (with and without retinopathy)

\begin{tabular}{|l|c|c|c|c|}
\hline \multirow{2}{*}{ HbA1c (\%) } & \multicolumn{2}{|c|}{ Type 2 diabetic patients } & \multirow{2}{*}{ T. Test } & \multirow{2}{*}{ P. value } \\
\cline { 2 - 3 } & Retinopathy (n:30) & Without Retinopathy (n:30) & \multirow{2}{*}{13.62} & $<0.001$ \\
\cline { 1 - 3 } Mean \pm SD & $9.38 \pm 1.65$ & $7.66 \pm 0.79$ & \\
\hline Minimum & 6.9 & 6.1 & \\
\hline
\end{tabular}

The study showed that, the highest mean of serum CRP was recorded in DM patients $(7.89 \pm 1.76 \mathrm{mg} / \mathrm{dl})$, as compared with the control group $(4.51 \pm 0.72 \mathrm{mg} /$ dl) $(\mathrm{P}<0.001)$, Table 5. The study also found that CRP was elevated significantly $(\mathrm{P}<0.001)$ in $\mathrm{DR}$ patients $(9.37 \pm 1.11 \mathrm{mg} / \mathrm{dl})$ as compared with diabetic without retinopathy patients $(6.41 \pm 0.73 \mathrm{mg} / \mathrm{dl})$, Table 6 .

Table 5: Levels of C-reactive protein in the studied groups

\begin{tabular}{|l|c|c|c|c|}
\hline C-Reactive protein (mg/dl) & Type 2 diabetic patients (n:60) & Control group (n:30) & T. Test & P. value \\
\cline { 1 - 3 } Mean & 7.89 & 4.51 & \multirow{2}{*}{12.43} & $<0.001$ \\
\cline { 1 - 2 } & 1.76 & 0.72 & & \multirow{2}{*}{ SD } \\
\hline
\end{tabular}

Table 6: Levels of C-reactive protein in DM patients (with and without retinopathy)

\begin{tabular}{|l|c|c|c|c|}
\hline \multirow{2}{*}{ C-Reactive protein (mg/dl) } & \multicolumn{2}{|c|}{ Type 2 diabetic patients } & \multirow{2}{*}{ T. Test } & \multirow{2}{*}{ P. value } \\
\cline { 2 - 3 } & Retinopathy (n:30) & Without retinopathy (n:30) & \multirow{2}{*}{12.15} & $<0.001$ \\
\cline { 1 - 3 } Mean \pm SD & $9.37 \pm 1.11$ & $6.41 \pm 0.73$ & & \\
\hline Minimum & 7.6 & 5.1 & & \\
\hline
\end{tabular}

Table 7 shows that $60 \%$ DR patients suffered from T2D for more than 9 years and 40\% suffered DM for 7-9 years while all diabetic patients without retinopathy were suffered from T2D for $\leq 9$ years with a significant relation between $\mathrm{Dr}$ and the duration of diabetes $(\mathrm{P}<0.001)$ 
Table 7: Relation of diabetic retinopathy with the duration of diabetes

\begin{tabular}{|l|c|c|c|c|}
\hline \multirow{2}{*}{ Duration of diabetes (years) } & \multicolumn{4}{|c|}{ Type 2 diabetic patients } \\
\cline { 2 - 5 } & \multicolumn{2}{|c|}{ Retinopathy } & \multicolumn{3}{|c|}{ Without retinopathy } \\
\cline { 2 - 5 } & No. & No. & 53.33 \\
\hline $3-6$ & 0 & 0 & 16 & 46.67 \\
\hline $7-9$ & 12 & 40 & 0 & 0 \\
\hline$>9$ & 18 & 60 & $\mathbf{3 0}$ & $\mathbf{1 0 0}$ \\
\hline
\end{tabular}

P. value: $0.0001 \mathrm{X}^{2}: 34.5\left(\mathrm{X}^{2}\right.$ : Chi square)

\section{Discussion}

The study revealed that the highest mean of $\mathrm{HbA1c}$ was found in DM patients $(8.39 \pm 1.62 \%)$ as compared by the control group $(4.91 \pm 0.43 \%)(\mathrm{P}<0.001)$, Table 1 . The study also found that $\mathrm{HbA} 1 \mathrm{c}$ was elevated significantly $(\mathrm{P}<0.001)$ in $\mathrm{DR}$ patients $(9.38 \pm 1.65 \%)$ comparing with DM patients without retinopathy $(7.66 \pm 0.79 \%)$ $(\mathrm{P}<0.001)$, Table 2 .

In agreement, Al-Ramadhan ${ }^{(11)}$ study showed that, HbA1c was elevated significantly in DR group followed by $\mathrm{DM}$ patients and indicating that poor glycemic control is a strong predictor for the development of DR. The elevated levels of HbA1c in DR patients may be due to their induction of retinal inflammation and vascular leakage due to their effect on blood vessels which may lead to retinal cell death ${ }^{(12)}$.

The study showed that, the highest mean of serum CRP was recorded in DM patients $(7.89 \pm 1.76 \mathrm{mg} / \mathrm{dl})$, as compared with the control group $(4.51 \pm 0.72 \mathrm{mg} /$ dl) $(\mathrm{P}<0.001)$, Table 3 . The study also found that CRP was elevated significantly $(\mathrm{P}<0.001)$ in $\mathrm{DR}$ patients $(9.37 \pm 1.11 \mathrm{mg} / \mathrm{dl})$ as compared with diabetic without retinopathy patients $(6.41 \pm 0.73 \mathrm{mg} / \mathrm{dl})$, Table 4 .

Our findings were also in agreement with the study done by $\mathrm{Du}$ et al (13) and Yasir et al (14), they found the hsCRP level was elevated more frequently in DR patients followed by NDR patients as compared with the control group. Moreover, AL-Harbi ${ }^{(15)}$ data indicated that, serum CRP level had significant increase in T2DM group compared with control group.

Based on the previous investigation of CRP, it has been hypothesized that elevated CRP levels may be beneficial in the pre-proliferative stages of DR by relieving ischemia, up-regulating the expression of vascular endothelial growth factor A and thus increasing retinal perfusion ${ }^{(16)}$. Collectively, the role of CRP in the inflammatory process is rather complicated as this protein may initiate and/or modulate multiple responses of the host and in this current study it is suggested that CRP may play a protective role in the DR pathogenesis ${ }^{(17)}$.

Table 5 shows that $60 \%$ DR patients suffered from T2D for more than 9 years and 40\% suffered DM for 7-9 years while all diabetic patients without retinopathy were suffered from T2D for $\leq 9$ years with a significant relation between DR and the duration of diabetes $(\mathrm{P}<0.001)$.Cheng et al ${ }^{(18)}$ revealed that, the presence of $\mathrm{DR}$ is strongly related to the duration of diabetes, with an approximate three-fold increase in vision-threatening DR in those who have had DM for 10 years or more. Menzel et al ${ }^{(19)}$ also studied association of various risk factors with diabetic retinopathy and found significant relation of $\mathrm{HbA1c}$ with DR $(\mathrm{P}<0.001)$. Zhou et al ${ }^{(20)}$ showed in similar study a significant relation of diabetic retinopathy with duration of diabetes $(\mathrm{P}<0.03)$. There is a strong positive relationship between the duration of diabetes and prevalence and progression of $\mathrm{DR}^{(21)}$. The prevalence of any DR increased from $21.1 \%$ in subjects with diabetes of 10 years duration to $54.2 \%$ with duration between 10 and 20 years to $76.3 \%$ with $\geq 20$ years disease duration in the META-EYE study ${ }^{(22)}$.

The study showed that serum omentin-1 was reduced significantly $(\mathrm{P}<0.001)$ in $\mathrm{DM}$ patients $(15.29 \pm 3.69 \mathrm{ng} / \mathrm{ml})$ as compared with the control group $(24.95 \pm 4.22 \mathrm{ng} / \mathrm{ml})$, Table 6 . The study also showed that serum omentin-1 was reduced significantly $(\mathrm{P}<0.001)$ in DR patients $(12.39 \pm 2.21 \mathrm{ng} / \mathrm{ml})$, comparing with $\mathrm{DM}$ patients without retinopathy $(17.52 \pm 2.28 \mathrm{ng} / \mathrm{ml})$, Table 7. 
Korany et al (23) also found that, serum omentin-1 level was significantly lower in diabetic patients compared with the control, and in DR compared with diabetics without DR. Omae et al (24) also found that, serum omintin-1 was reduced significantly $(\mathrm{P}<0.001)$ in DR patients, comparing with DM patients without retinopathy. Additionally, in recent meta-analysis study showed that serum level of omentin was significantly lower in T2DM compared to healthy controls ${ }^{(25)}$.

The possible explanation for this phenomenon is that, as omentin- 1 could increases insulin sensitivity, its decrease may be the cause of impaired glucose homeostasis in prediabetic patients ${ }^{(1,3)}$.

Omentin-1 is important for glucose metabolisminvitro, omentin-1 increases insulin signal transduction by activating the protein kinase $B$ and enhances insulinmediated glucose transport in adipocytes. A clinical study of patients suffering from diabetes mellitus, reported that serum and vitreous omentin levels were related to the severity of DR, and experimental investigations have shown that omentin has a potent vasodilatory effect in isolated vessels mediated by endothelium derived nitric oxide, a strong vasodilator of the retinal arterioles ${ }^{(26)}$.

The study showed negative correlation between omentin-1 and duration of DM, Figure 1.

Korany et al (23) also found that, serum omentin-1 level was negatively correlated with DM duration. Interestingly, El-Mesallamy et al (27) also found that, omentin-1 was negatively correlated with duration of DM.

The study showed negative correlation between omentin-1 and BMI of DM patients, Figure 2.

In agreement with this finding, Korany et $\mathrm{al}^{(23)}$ found that, serum omentin-1 level had a negative significant correlation with BMI in DM patients. Some studies have also shown that omentin-1 serum levels were generally lower in obese groups with or without type $2 \mathrm{DM}^{(28)}$. In a study performed by de souza Batista et al ${ }^{(29)}$ plasma levels of omentin were measured in lean, overweight, and obese, otherwise healthy subjects. The authors found that plasma omentin levels were highest among the lean subjects and these levels were inversely correlated with BMI. Our results were agreed with the findings reported by other studies that demonstrated significant negative correlation between plasma omentin-1 concentrations and patients $\mathrm{BMI}^{(30-31)}$.
Financial Disclosure: There is no financial disclosure.

Conflict of Interest: None to declare.

Ethical Clearance: All experimental protocols were approved under the Kirkuk Health Directorate and all experiments were carried out in accordance with approved guidelines.

\section{References}

1. Scanlon $\mathrm{PH}$, Sallam A, Van Wijngaarden $\mathrm{P}$, editors. A practical manual of diabetic retinopathy management. John Wiley \& Sons. 2017.

2. Ola MS, Alhomida AS. Mediterranean Diet and Diabetic Retinopathy. InRole of the Mediterranean Diet in the Brain and Neurodegenerative Diseases 2018; 171-181.

3. Robberecht $\mathrm{H}$, Hermans N. Biomarkers of metabolic syndrome: biochemical background and clinical significance. Metabolic syndrome and related disorders. 2016;14(2):47-93.

4. Schachat AP, Wilkinson CP, Hinton DR, Wiedemann P, Freund KB, Sarraf D. Ryan's Retina E-Book. Elsevier Health Sciences; 2017; 17.

5. Bandello F, Zarbin MA, Lattanzio R, Zucchiatti I, editors. Management of Diabetic Retinopathy. Karger Medical and Scientific Publishers; 2017 Apr 20.

6. AL-Jedda WA, Al-Sharifi AN, AL-Taie MA. Measurement of Serum Omentin-1 in Patients with Acute Coronary Syndrome. Mustansiriya Medical Journal. 2016;15(1):57-64.

7. Ola MS, Alhomida AS. Mediterranean Diet and Diabetic Retinopathy. InRole of the Mediterranean Diet in the Brain and Neurodegenerative Diseases 2018: 171-181.

8. American Diabetes Association. Classification and diagnosis of diabetes. Diabetes care. 2017;40 (Supplement 1):S11-24.

9. Harris-Hayes M, Schootman M, Schootman JC, Hastings MK. The Role of Physical Therapists in Fighting the Type 2 Diabetes Epidemic. Journal of orthopaedic \& sports physical therapy. 2020;50(1):5-16.

10. Papatheodorou K, Banach M, Bekiari E, Rizzo M, Edmonds M. Complications of diabetes 2017. Journal of diabetes research. 2018. 
11. Al-Ramadhan AR. Glycemic control (hba1c) in patients with diabetic retinopathy. Thi-Qar Medical Journal. 2011;5(3):103-8.

12. Thapa R, Joshi DM, Rizyal A, Maharjan N, Joshi RD. Prevalence, risk factors and awareness of diabetic retinopathy among admitted diabetic patients at a tertiary level hospital in Kathmandu. Nepalese Journal of Ophthalmology. $2014 \mathrm{Jul}$ 16;6(1):24-30.

13. Du J, Li R, Xu L, Ma R, Liu J, Cheng J, Zhang Z, Sun H. Increased serum chemerin levels in diabetic retinopathy of type 2 diabetic patients. Current eye research. 2016;41(1):114-20.

14. Yasir M, Senthilkumar GP, Ramesh-Babu K, Vadivelan M. Evaluation of novel adipokines (omentin-1, apelin and chemerin) as potential biomarkers of presence and severity of diabetic retinopathy in type 2 diabetes patients. InDIABETOLOGIA 2019 Sep 1 (Vol. 62, pp. S505-S505). 233 SPRING ST, NEW YORK, NY 10013 USA: SPRINGER.

15. AL-Harbi HJ. Circulating Level of Serum Chemerin and CRP in Type 2 Diabetes Mellitus Patients with and Without Hypertension in Menopauses Women. Journal of University of Babylon. 2018; 26(1):132-9.

16. Sen D, Ghosh S, Roy D. Correlation of C-reactive protein and body mass index with diabetic retinopathy in Indian population. Diabetes Metab Syndr 2015;9(1):28-9.

17. Muni RH, Kohly RP, Lee EQ, Manson JE, Semba RD, Schaumberg DA. Prospective study of inflammatory biomarkers and risk of diabetic retinopathy in the diabetes control and complications trial. JAMA Ophthalmol. 2013;131(4):514-521.

18. Cheon DY, Kang JG, Lee SJ, Ihm SH, Lee EJ, Choi MG, Yoo HJ, Kim CS. Serum chemerin levels are associated with visceral adiposity, independent of waist circumference, in newly diagnosed type 2 diabetic subjects. Yonsei medical journal. 2017;58(2):319-25.

19. Menzel J, di Giuseppe R, Biemann R, Wittenbecher C, Aleksandrova K, Eichelmann F, Fritsche A, Schulze MB, Boeing H, Isermann B, Weikert C. Association between chemerin, omentin-1 and risk of heart failure in the population-based EPICPotsdam study. Scientific reports. 2017;7(1):1-9.
20. Zhou Q, Fu Y, Hu L, Li Q, Jin M, Jiang E. Relationship of circulating chemerin and omentin levels with Th17 and Th9 cell immune responses in patients with asthma. Journal of Asthma. 2018;55(6):579-87.

21. Kempen JH, O’Colmain BJ, Leske MC, Haffner SM, Klein R, Moss SE, Taylor HR, Hamman RF; Eye Diseases Prevalence Research Group: The prevalence of diabetic retinopathy among adults in the United States. Arch Ophthalmol 2004;122:552563.

22. Dehghan MH, Katibeh M, Ahmadieh H, Ramezani A, Moradian S, Noorinia R, Ziaei H, Mahdavi AR, Naghib J, Toosi A, Azarmina M. Prevalence and risk factors of diabetic retinopathy in Yazd Province. Bina Journal of Ophthalmology. 2013;18(4):37591.

23. Korany MA, Sonbol A, Elgouhary SM. Omentin-1 and diabetic retinopathy in type 2 diabetic patients. Alexandria journal of medicine. 2018;54(4):323-6.

24. Omae T, Nagaoka T, Yoshida A. Effect of Circulating Omentin-1 on the Retinal Circulation in Patients with Type 2 Diabetes Mellitus. Investigative ophthalmology \& visual science. 2017;58(12):5086-92.

25. As A. The association between omentin and diabetes: a systematic review and meta-analysis of observational studies. Diabetes, metabolic syndrome and obesity: targets and therapy. 2019; 12:1277.

26. Wan W, Li Q, Zhang F. Serum and vitreous concentrations of omentin-1 in diabetic retinopathy. Dis Markers. 2015;754312.

27. El-Mesallamy HO, El-Derany MO, Hamdy NM. Serum omentin-1 and chemerin levels are interrelated in patients with Type 2 diabetes mellitus with or without ischaemic heart disease. Diabetic Medicine. 201;28(10):1194-200.

28. Tan BK, Adya R, Randeva S. Omentin: a novel link between inflammation, diabesity, and cardiovascular disease. Trends Cardiovasc Med. 2010;20:143-148.

29. de Souza Batista CM, Yang RZ, Lee MJ, et al. Omentin plasma levels and gene expression are decreased in obesity. Diabetes. 2007;56:16551661. 
30. Tok A, Ozer A, Kanat-Pektas M, Aral M, Sakalli H, Aydogdu S, Yutan-Kaya E, Sager H. The role of omentin in early pregnancy losses. Journal of Obstetrics and Gynaecology. 2020;40(1):107-10.
31. Gateva A, Assyov Y, Tsakova A, Kamenov Z. Classical (adiponectin, leptin, resistin) and new (chemerin, vaspin, omentin) adipocytokines in patients with prediabetes. Hormone molecular biology and clinical investigation. 2018;34(1). 